\title{
СТАВОВИ НАСТАВНИКА О ФУНКЦИЈИ ЈЕЗИКА У БИЛИНГВАЛНОЈ НАСТАВИ
}

\begin{abstract}
Билингвална настава као предмет истраживања из угла методике и дидактике наставе страних језика као и методике наставе стручних предмета обухвата многе аспекте наставе. Један од важнијих је свакако страни језик, а могуће теме истраживања су језик наставе, језик ученика или језик наставника. Циљ овог рада је анализа ставова наставника о сврси и функцији језика у двојезичној настави, а фокус на језику наставника. Ово истраживање је основа за увид у потребе наставника у двојезичној настави у погледу језика и доношење предлога о језичком усавршавању и наставним материјалима. Испитани су ставови наставника у две гимназије у којима ова врста наставе постоји неколико година. Показало се да постоји потреба за повећањем језичког нивоа, сталним језичким усавршавањем, материјалима на страном језику, различити ставови о улози страног лектора у билингвалној настави, а слично схватање сврхе и функције страног језика у билингвалној настави.
\end{abstract}

Кључне речи: билингвална настава, функција језика, језик наставника, језик наставе, ставови наставника

\section{1. Увод}

Овај рад настао је у оквиру интерног пројекта Центра за стране језике и Департмана за немачки језик и књижевност Филозофског факултета Универзитета у Нишу у току школске 2018/2019. године под називом Курсеви страних језика: теоријске поставке и практичне импликације у коме су исте испитиване у ширем контексту високог образовања. Реч је о курсевима страних језика који се изучавају на нематичним филолошким и нефилолошким департманима као изборни предмети, али и кроз ваннаставне активности (факултативни језички или методички курсеви за посебне циљне групе као што су студенти, наставници, сарадници Факултета и Универзитета, наставници средњих школа итд.).

1 nevenka.jankovic@filfak.ni.ac.rs 
Једно од истраживања у оквиру пројекта у вези је са импликацијама курсева страних језика и језичко-методичке обуке наставника који изводе или ће изводити наставу из своје академске дисцилине на страном језику (билингвална настава). Обухваћени сегменти учења и наставе страних језика су подстицање аутономије у професионалној употреби страног језика, мотивисаност за целоживотно учење страног језика за потребе професије, развијање свести о значају практичне употребе страног језика у одређеној струци и професији итд. Пројекат има за циљ унапређење и диверсификацију наставе и курсева страних језика, базирајући се на резултатима анализе ставова студената, полазника курсева страних језика и наставника нејезичких предмета у билингвалним одељењима, у вези са значајем учења језика за примену у професији и будуће стручно усавршавање.

Један од специфичних циљева је доношење предлога за обуку наставног особља за успешно извођење билингвалне наставе, а очекивани исходи су и израда силабуса за учење страног језика за потребе струке и професије, давање смерница за унапређење курсева страних језика у циљу практичне примене стечених знања, вештина и компетенција у струци и професији. Један од задатака је и анкетирање наставника нејезичких предмета у вези са сврхом и доприносом примене језика у оквиру истих (коришћење извора на страном језику и билингвална настава). С обзиром на то да већ постоји сарадња Филозофског факултета у Нишу и нишких гимназија у којима постоје билингвална одељења на енглеском, немачком и француском језику (језичко-методичка обука), резултати овог пројекта ће допринети даљој сарадњи ових образовних институција у погледу практичне примене језика у билингвалној настави.

\section{1. Циљ и предмет емпиријског истраживања у оквиру пројекта}

У поменутом пројекту учествовало је више запослених, док је сегмент посвећен билингвалној настави реализовало троје наставника и сарадника, а за потребе овог рада биће анализирани подаци у вези са наставницима који изводе наставу на немачком и енглеском језику (са посебним освртом на наставнике у немачко-српској настави, који ће у новом пројектном циклусу бити анкетирани у погледу методике и дидактике билингвалне наставе). ${ }^{2}$

Циљ емпиријског истраживања је испитивање ставова наставника предмета из области друштвено-хуманистичких и природно-математичких наука у билингвалним одељењима о примени и функцији страног језика у двојезичној настави, сопственом језичком нивоу и језичком

2 Доц. др Весна Симовић ће се у посебном раду бавити анализом података у вези са наставницима који изводе наставу на француском и српском језику.

$$
\overline{974}
$$


усавршавању. Анкетирани су наставници гимназија „Бора Станковић“у Нишу и Прве нишке гимназије „Стеван Сремац“, у којима више година постоје билингвална настава на енглеском и српском, односно немачком и српском језику. Задаци овог емпиријског истраживања односе се на испитивање ставова наставника о:

- постојећем и неопходном језичком нивоу наставника за успешно извођење наставе,

- потреби за језичким усавршавањем наставника и о облицима усавршавања,

- сврси и функцији страног језика у двојезичној настави за наставнике,

- сврси и функцији страног језика у двојезичној настави за ученике.

\section{2. Теоријски оквир рада}

\section{1. Језик ученика}

ЦЛИЛ (CLIL - Content and language Integrated Learning) дефинишу Марш, Мехисто и др. (MARŠ, MEHISTO I DR. 2010: 13) као дуално фокусиран образовни приступ у коме се додатни језик користи за наставу и учење нејезичког предмета и језика у циљу савладавања предмета и језика на одређеном нивоу. ЦЛИЛ подразумева прожимање страног језика и градива стручног предмета, те су осим компетенција у страном језику и стручном предмету потребне и специфичне попут регистра страног језика струке или теорија усвајања Л2 итд., истиче Волф (VOLF 2002: 260-267). Зато су циљеви двојезичне наставе вишеструки (садржајни, когнитивни и језички), а подршка вишејезичности се пружа двојако: кроз страни и кроз матерњи језик. Када говоримо о језичким циљевима у ЦЛИЛ-у, ту спадају језичке компетенције циљног језика, усмене комуникативне вештине, интеркултурне комуникативне вештине, терминологија одређеног предмета итд.

Предности двојезичне наставе су многоструке. Према Волфу (VOLF 2011: 77-80) она отвара нове перспективе у погледу стручног предмета и језика, подржава језичке компетенције ученика, нарочито у погледу дискурсне компетенције и професионалног, тј. регистра језика струке, даје ученицима нове импулсе, повећава мотивацију. Волф (VOLF 2011: 82) даље истиче да путем тзв. сензибилног подучавања двојезична настава може да утиче на иновације у настави, а преношење ове методе на друге предмете може довести до проширења компетенција ученика у школском језику. Према Лајзену (LAJZEN 2011: 17-18) језички сензибилна настава стручних предмета негује свестан однос према језику и схвата 
језик као медијум који не ремети учење стручних садржаја, а са друге стране препознаје језик као тему у стручном предмету (учење језика нераскидиво повезано за учењем стручних садржаја). Школски језик је онај на коме се одвија настава, другачији од свакодневног, језик академског регистра, нов за ученике попут страног језика, и у том смислу повећава језичке и дискурсне компетенције, сматра Волф (VOLF 2011: 79).

Постоје два начина владаға језиком: усмена комуникација у интеракцији са другима (свакодневица) и вербализација сложених когнитивних процеса. У настави страног језика долази до развоја компетенција БИЦС (Basic Interpersonal Communication Skills), док је за наставу ЦЛИЛ карактеристичан развој компетенција ЦАЛП (Cognitive Academic Language Proficiency), што чини дихотомију, карактеристичну за ЦЛИЛ (акроними Каминса (KAMINS 1987, 2008). С обзиром на то да према Лајзену (LAJZEN 2013: 59) академски језик настаје у контекстуално редукованим школским ситуацијама, у когнитивном академском подручју као језик образовања, у коме ученици повећавају когнитивне академске вештине, ЦЛИЛ може да омогући развој школског језика. Језик у двојезичној настави има посебну сврху и функцију, не посматра се само са аспекта ученика, већ и са аспекта наставника и наставе. Он може бити језик наставних садржаја, комуникације у настави или конкретних знања. Којл (KOJL 2007), Којл, Худ и др. (KOJL, HUD I DR. 2010) називају ово тројство језички триптих (Language Tryptich): language of learning, language for learning и language trough learning.

Иако су језик ученика и компетенције које они стичу у билингвалној настави главни циљ различитих истраживања, неопходно је и истраживање језика и компетенција наставника у циљу континуиране подршке. Наиме, иако је концепт билингвалне наставе заживео у школама, наставници нису имали иницијално образовање за ЦЛИЛ, те је неопходно усавршавање, сарадња наставника, едукатора и школа, полазећи од потреба наставника. У овом раду бавимо се језичким компетенцијама наставника у ЦЛИЛ-у које су предуслов успешне реализације исте, анализом ставова наставника.

2.2. Језик наставника и професионалне компетенције у билингвалној настави

Осим садржаја стручног предмета наставник у двојезичној настави преноси ученицима језичка знања, при чему се ради и о језику одређених карактеристика и одређеног регистра, језику учионице, ученика и наставника. За то су наставнику потребне многе компетенције. Хилјард (HILJARD 2011: 5) предлаже усавршавање у смислу интензивног развоја језика (укључујући језик учионице), развој знања садржаја 
(укључујући концепте и вештине на когнитивном нивоу) и методологију ЦЛИЛ-а (укључујући исходе, графичке организаторе, Блумову таксономију, БИЦС И ЦАЛП, различите приступе ЦЛИЛ-а и учене кроз рад).

Потребна су истраживања у погледу језичких компетенција и потреба наставника у језичком погледу. На школама и наставницима је да савладавају потешкоће које настава ЦЛИЛ-а доноси, а о индивидуалним потребама предметних наставника и свакодневној подршци не могу се често чути анализе. Након увођења ЦЛИЛ-а неопходно је сагледавати проблеме у погледу примене и функције страног језика у ЦЛИЛ настави, језичких и методских компетенција наставника. Поставља се најпре питање језичких компетенција наставника, језичким знањима и језику струке. Затим питања о томе, да ли похађају курсеве језика или усвајају језик у природној средини, како одржавају ниво знања језика, да ли се усавршавају, да ли им је потребна помоћ лектора и наставника страних језика итд.

Европски оквир за образоване ЦЛИЛ наставника (MARŠ, MEHISTO I DR. 2010) је оријентир за установе, наставнике и инструкторе у процени циљних професионалних компетенција којима ЦЛИЛнаставник треба да тежи у усавршавању и да подстиче професионалну рефлексију. У домену компетенције ПРОМИШљАҢЕ очекује се да наставници:

- истраже своје разумевање и ставове у односу на учење нејезичког предмета и језика (Л1, Л2, Л3) и развој вештина учења у ЦЛИЛ-у, - дефинишу сопствени ниво језичке компетенције према Заједничком европском референтном оквиру,

- изразе развојне потребе, потребе за сарадњом са колегама и другим учесницима у ЦЛИЛ-у итд. (MARŠ, MEHISTO I DR. 2010: 19).

У погледу компетенције СВЕСТ О ОДНОСУ НЕЈЕЗИЧКОГ САДРЖАЈА И ЈЕЗИКА истиче се да успех у учењу нејезичког предмета зависи од језика, а да се језик унапређује учењем стручног предмета, да постоји међузависност свих ученикових језика (Л1, Л2, Л3) и когнитивног развоја (MARŠ, MEHISTO I DR. 2010: 20), а од наставника се очекује да:

- примењују стратегије неговања критичког размишљања о језику и нејезичком предмету,

- промовишу свест о језику и процес учења језика,

- прилагођавају стратегије за прелазак ка вишејезичком учењу,

- повезују питања језичке свести са учењем предмета и когницијом,

- подрже учење језика током часова нејезичког предмета, 
- користе знања из области учења и усвајања језика итд. (MARŠ, MEHISTO I DR. 2010: 21-22).

Полазећи од циљних компетенција, а узимајући у обзир сврху и функцију језика у ЦЛИЛ-у, овим истраживањем смо подстакли рефлексију наставника о језичким аспектима. У ту сврху је испитанциима постављено више питања како би стекли увид у ставове и потребе у погледу језика и донели закључке у вези са усавршавањем наставника и наставним материјалима.

\section{3. Емпиријско истраживање}

Испитивање је имало за циљ прикупљање података ради стицање увида у мишљења наставника о сопственом владању страним језиком, потреби за језичким усавршавањем, облицима усавршавања, као и ставове о сврси и функцији коју страни језик остварује у ЦЛИЛ-у са аспекта наставника и ученика.

\section{1. Испитаници}

Табела 1. Структура наставника

\begin{tabular}{|c|c|c|c|c|c|}
\hline & $\begin{array}{l}\text { Бр. } \\
\text { исп. }\end{array}$ & $\begin{array}{c}\text { Већински тип } \\
\text { предмета }\end{array}$ & $\begin{array}{c}\text { Језик } \\
\text { наставе }\end{array}$ & $\begin{array}{l}\text { Просечно } \\
\text { искуство } \\
\text { у настави }\end{array}$ & $\begin{array}{c}\text { Просечно } \\
\text { искуство } \\
\text { у двојезичној } \\
\text { настави }\end{array}$ \\
\hline $\begin{array}{c}\text { „Бора } \\
\text { Станковић“ }\end{array}$ & 11 & $\begin{array}{c}\text { природно- } \\
\text { математички }\end{array}$ & Енглески & 10 година & 3 године \\
\hline $\begin{array}{l}\text { „Стеван } \\
\text { Сремац“ }\end{array}$ & 9 & $\begin{array}{c}\text { друштвено- } \\
\text { хуманистички/ } \\
\text { уметност }\end{array}$ & Немачки & 18 година & 4 године \\
\hline
\end{tabular}

Анкетирано је укупно 20 наставника у две школе. Наставници енглеско-српске двојезичне наставе имају просечно наставно искуство од око 10 година $(9,75)$. Петоро наставника од 6 до 10 година стажа, четворо од 11 до 18 година, док само двоје ради краће од 5 година. Иако је реч о релативно искусним наставницима, њихов рад у двојезичној настави износи у просеку само три године. Наиме, три наставника $(27,27 \%)$ раде између 0 и 18 месеци, четворо између три и четири године (36,36\%), а два између 6 и $7(18,18 \%)$. У немачко-српској двојезичној настави просечни радни век испитаних наставника је 18 година, док су у двојезичној настави просечно 4 године, слично као у енглеско-српској. Наиме, четворо наставника $(44,44 \%)$ има искуство од четири године, троје $(33,33 \%)$ од пет и два $(22,22 \%)$ наставника од три године. У погледу стручних предмета већина испитаника (72,73\%) енглеско-српске наставе предаје при- 
родно-математичке предмете: математику $(27,27 \%)$, биологију $(18,18 \%)$, хемију $(18,18 \%)$ и физику $(9,09 \%)$. Само три наставника $(27,27 \%)$ предају предмете из области друштвено-хуманистичких наука: филозофију, психологију и двојну науку географију. За разлику од њих, у наставу на немачком језику укључени су наставници друштвено-хуманистичких наука и уметности (шесторо односно 66,67\%): српски језик 33,33\%, историја $22,22 \%$, ликовно $11,11 \%$, док је само двоје $(22,22 \%)$ из техничких наука (информатика) и један $(11,11 \%)$ из географије.

\section{2. Резултати истраживања}

Подаци су прикупљени уз помоћ анонимог упитника, који се састојао из 16 питања затвореног и отвореног типа, на основу којих су добијени следећи резултати:

Табела 2. Самопроиена нивоа језичких знаға предметних наставника

\begin{tabular}{|c|c|c|c|c|c|c|}
\hline & Б2 & Б1 & А2 & А2-А1 & А1 & без процене \\
\hline $\begin{array}{c}\text { „Бора } \\
\text { Станковић“ }\end{array}$ & $63,64 \%$ & $18,18 \%$ & $9,09 \%$ & --- & --- & $9,09 \%$ \\
\hline $\begin{array}{c}\text { „теван } \\
\text { Сремац“ }\end{array}$ & --- & --- & $44,44 \%$ & $11,11 \%$ & $44,44 \%$ & -- \\
\hline
\end{tabular}

Табела 3. Процена потребног нивоа језичког знана за извођене предметне наставе

\begin{tabular}{|c|c|c|c|c|c|c|c|c|}
\hline & Ц2 & Ц1 & Ц2-Ц1 & Б2/Ц1 & Б2 & Б2-Б1 & Б1 & А2 \\
\hline $\begin{array}{c}\text { „Бора } \\
\text { Станковић“ }\end{array}$ & --- & $18,18 \%$ & ---- & $9,09 \%$ & $63,64 \%$ & --- & --- & $9,09 \%$ \\
\hline $\begin{array}{c}\text { „Стеван } \\
\text { Сремац“ }\end{array}$ & --- & --- & $33,33 \%$ & --- & --- & $66,67 \%$ & --- & --- \\
\hline
\end{tabular}

Из Табеле 2. може се видети да већина наставника у енглескосрпској настави сматра да поседује висок ниво знања енглеског (Б2) који омогућава самосталност у коришћењу језика. Два испитаника проценила су свој ниво као Б1, један наставник као А2, док један није дао процену. Када је у питању процена потребног језичког знања (Табела 3), за већину наставника (седморо или $63,64 \%$ ) ниво Б2 је довољан за извођење двојезичне наставе на енглеском језику. Са овим ставом не слажу се четири наставника, што чини мало више од трећине $(36,36 \%)$, који су мишљења да је за успешно извођење двојезичне наставе потребно познавање енглеског на вишем међунивоу Б2/Ц1 (један наставник), затим вишем нивоу Ц1 (два наставника), или пак нижем нивоу А2 (један настав- 
ник). Насупрот овоме, наставници у немачко-српском ЦЛИЛ-у сматрају да владају немачким језиком на почетном А1 (44,44\%) или А2 (44,44\%), нивоу, а један на међунивоу А1-А2 (11,11\%). Њихове амбиције су веће и скоро сви теже вишим нивоима: Б1 или Б2 (2/3 наставника, 66,66\%), Ц1 или Ц1-Ц2 (трећина тј. 33,33\%), док само један тежи нижем нивоу А2-Б1.

Табела 4. Похађаюе језичких курсева од стране наставника у ииљу усавршавана

\begin{tabular}{|l|l|c|}
\hline & енглески & немачки \\
\hline $\begin{array}{l}\text { У организацији } \\
\text { матичне школе }\end{array}$ & \multicolumn{1}{|c|}{$54,54 \%$} & $55,55 \%$ \\
\hline $\begin{array}{l}\text { Плаћени курс у } \\
\text { иностранству }\end{array}$ & \multicolumn{1}{|c|}{$18,18 \%$} & $66,67 \%$ \\
\hline $\begin{array}{l}\text { Индивидуални } \\
\text { часови језика }\end{array}$ & $\begin{array}{l}\text { културни центар 9,09\% } \\
\text { приватна школа 9,09\% } \\
\text { језика }\end{array}$ & \multirow{2}{*}{$22,22 \%$} \\
\cline { 2 - 3 } Друго & $\begin{array}{l}\text { Филозофски 9,09\% } \\
\text { факултет }\end{array}$ & \multirow{2}{*}{$22,22 \%$} \\
\hline
\end{tabular}

Табела 5. Самофинансираюе језичких курсева од стране наставника

\begin{tabular}{|c|c|c|}
\hline & ДА & HЕ \\
\hline енглески & $36,36 \%$ & $63,64 \%$ \\
\hline немачки & $22,22 \%$ & $77,78 \%$ \\
\hline
\end{tabular}

Скоро сви испитаници гимназије у енглеско-српској настави, 10 од 11 укупно, сматрају да им је потребно даље усавршавање енглеског. Исто је и са свим наставницима у немачко-српској настави, који желе да унапреде знање немачког. Више од половине испитаника у енглеско-српској настави жели да курс језика буде организован од стране матичне школе $(54,54 \%)$, као други најчешћи избор следи плаћени курс у иностранству $(27,27 \%)$ или индивидуални курс језика $(18,18 \%)$. Када је у питању финансирање усавршавања, само трећина (36,36\%) је спремна да издвоји лична средства, док већина од 63,64\% жели бесплатне курсеве. Наставници у немачко-српској настави направили су следећи избор: на првом месту је плаћени курс у иностранству (66,67\%), следи курс организован у матичној школи $(55,55 \%)$ и као трећи избор индивидуални часови или други начин (по 22,22\%), а већина (две трећине) није у могућ- 
ности да сама финансира курс.

Испитаницима је постављено питање о сврси језичких знања наставника у двојезичној настави (Табела 6).

Табела 6. Сврха (добрих) језичких знағь у двојезичној настави

\begin{tabular}{|c|c|c|c|c|}
\hline & $\begin{array}{c}\text { Коришћење } \\
\text { страних } \\
\text { уџбеника }\end{array}$ & $\begin{array}{c}\text { Коришћење } \\
\text { додатних настав- } \\
\text { них материјала } \\
\text { на страном } \\
\text { језику }\end{array}$ & $\begin{array}{c}\text { Повећање } \\
\text { језичке } \\
\text { компетенције }\end{array}$ & $\begin{array}{c}\text { Коришћење } \\
\text { приручне } \\
\text { литературе } \\
\text { за припрему } \\
\text { наставе }\end{array}$ \\
\hline $\begin{array}{c}\text { „Бора } \\
\text { Санковић“ }\end{array}$ & $45,45 \%$ & $36,36 \%$ & $100 \%$ & $27,27 \%$ \\
\hline $\begin{array}{c}\text { „стеван } \\
\text { Сремац“ }\end{array}$ & $33,33 \%$ & $44,44 \%$ & $44,44 \%$ & $22,22 \%$ \\
\hline
\end{tabular}

Сви испитаници у енглеско-српској настави сматрају да је добро владање (наставника) енглеским језиком неопходно превасходно ради повећања језичке компетенције, затим коришћења страних уџбеника (скоро половина наставника), коришћења додатних наставних материјала на страном језику (добра трећина наставника), и најзад ради коришћења приручне литературе за припрему наставе (мало више од четвртине наставника). Приоритети наставника у немачко-српској настави су мало другачији: повећање језичке компетенције и коришћење додатних наставних материјала наводи као први избор (подједнако) мало мање од половине наставника, док су коришћење страних уџбеника и коришћење приручне литературе за припрему наставе битни за трећину односно четвртину наставника.

С обзиром на то да Правилник о ближим условима за остваривање двојезичне наставе (2015) предвиђа могућност ангажовања страног лектора, и да је иначе могућа сарадња са лекторима или наставницима страних језика, испитаницима је постављено питање у вези са могућом помоћи лектора. 
Philologia Mediana XIII/2021

Табела 7. Значај страног лектора у двојезичној настави

\begin{tabular}{|r|c|c|c|c|c|}
\hline & ДА & НЕ & $\begin{array}{c}\text { без } \\
\text { одговора }\end{array}$ & $\begin{array}{c}\text { дели- } \\
\text { мично }\end{array}$ & \multicolumn{1}{|c|}{ СВРХА } \\
\hline енглески & $36,36 \%$ & $18,18 \%$ & $45,45 \%$ & --- & $\begin{array}{l}\text { стручни појмови, } \\
\text { изговор, } \\
\text { акцентовање }\end{array}$ \\
\hline немачки & $44,44 \%$ & --- & $44,44 \%$ & $11,11 \%$ & -- \\
\hline
\end{tabular}

Помоћ лектора за енглески језик добродошла је за четворо $(36,36 \%)$ наставника Гимназије „Бора Станковић“, и то у погледу стручних математичких појмова и правилног изговарања и акцентовања. Експлицитно се двоје наставника изјаснило да им није потребан страни лектор, док скоро половина $(45,45 \%)$ испитаника није одговорила на ово питање. Чини се да за већину испитаника $(63,63 \%)$ помоћ страног лектора није приоритетна у двојезичној настави. Сличан став имају и наставници Гимназије „Стеван Сремац“, јер скоро половина $(44,44 \%)$ наставника је без одговора у вези са сарадњом са лектором за немачки језик. Ипак, подједнак број наставника сматра да им је помоћ лектора потребна, док само један наставник има неодлучан став.

Табела 8. Индивидуално повећағе језичких знаюа

\begin{tabular}{|l|c|c|}
\hline & $\begin{array}{c}\text { „Бора } \\
\text { Станковић“ }\end{array}$ & $\begin{array}{c}\text { „Стеван } \\
\text { Сремац“ }\end{array}$ \\
\hline Читам. & $54,54 \%$ & --- \\
\hline Гледам ТВ. & $45,45 \%$ & $44,44 \%$ \\
\hline Слушам музику. & $54,54 \%$ & $22,22 \%$ \\
\hline Користим апликације за учење језика. & $18,18 \%$ & $44,44 \%$ \\
\hline Комуницирам са изворним говорницима. & $18,18 \%$ & $55,55 \%$ \\
\hline Друго: индивидуални приватни часови & $9,09 \%$ & --- \\
\hline
\end{tabular}

Сви испитаници у енглеско-српској двојезичној настави раде на подизању нивоа знања енглеског, већина $(63,64 \%)$ наводи најмање најмање два или три начина. Више од половине испитаника чита литературу тј. текстове и слуша музику, а мање од половине гледа ТВ на енглеском, док у маюој мери наводе апликаиије за учене и комуникацију са изворним говорницима. Наставници у немачко-српској настави предност дају гледағьу телевизије и коришћену апликација (скоро половина), али највише живом контакту - разговору са изворним говорницима (више од половине). Слушање музике је избор малог броја наставника, док није- 
дан наставник не чита на немачком језику (могући разлог је недовољан језички ниво за читање аутентичних извора према самопроцени наставника). Треба истаћи да велики број ових испитаника наводи најмање два или три начина одржавања језичког знања, што указује на свест о значају континуираног унапређења језичких компетенција. Поред тога уочава се склоност ка модерном начину учења путем апликација.

Осим питања посвећених језичким знањима упитник је садржао и питања о наставном материјалу који одражава и језик струке. Испитаницима је понуђено пет различитих извора (Табела 9), у којима је заступљен српски или страни језик (или пак комбинација оба).

Табела 9. Вредноваюе наставних материјала у двојезичној настави

\begin{tabular}{|l|c|c|}
\hline & $\begin{array}{c}\text { „Бора } \\
\text { Станковић“ }\end{array}$ & $\begin{array}{c}\text { "Стеван } \\
\text { Сремац“ }\end{array}$ \\
\hline Домаћи уџбеник & $9,09 \%$ & $11,11 \%$ \\
\hline Страни уџбеник & $27,27 \%$ & $22,22 \%$ \\
\hline Комбинација домаћег и страног уџбеника & $45,45 \%$ & $66,67 \%$ \\
\hline Преведен домаћи уџбеник & $36,36 \%$ & $33,33 \%$ \\
\hline Скрипта на страном језику из више извора & $36,36 \%$ & $22,22 \%$ \\
\hline
\end{tabular}

Испитаници у енглеско-српској настави сматрају најкориснијом комбинацију домаћег и страног уибеника (45,45\%), затим у једнакој мери превод домаћег уибеника и скрипта на енглеском језику из више извора (по четири наставника), у мањој мери страни уцбеник (три наставника), док само један наставник сматра да је домаћи уибеник користан. За наставнике у немачко-српској настави убедљиво је најкориснија комбинаиија домаћег и страног уибеника, јер је већина од 66,67\% навела управо овај извор, затим само трећина преведен домаћи уџбеник, док су остали материјали равномерно, али мање заступљени.

Табела 10. Сврха и функција страног језика у двојезичној настави

\begin{tabular}{|l|c|c|}
\hline & $\begin{array}{c}\text { „Бора } \\
\text { Станковић“ }\end{array}$ & $\begin{array}{c}\text { Сртеванан“ } \\
\text { Сремај }\end{array}$ \\
\hline Стицање језичких знања & $54,54 \%$ & $55,56 \%$ \\
\hline Стицање стручних знања & $36,36 \%$ & $77,78 \%$ \\
\hline Стицање језичких и стручних знања & $18,18 \%$ & --- \\
\hline Развој интердисциплинарности & $18,18 \%$ & --- \\
\hline Коришћење вишејезичних извора информација & $54,54 \%$ & --- \\
\hline Развој комуникативне компетенције & $45,45 \%$ & $66,67 \%$ \\
\hline Развој вишејезичности & $27,27 \%$ & $44,44 \%$ \\
\hline Развој интеркултуралне компетенције & $18,18 \%$ & --- \\
\hline Развој целоживотног учења & $63,64 \%$ & $77,78 \%$ \\
\hline
\end{tabular}


Следећи блок питања постављен је у вези са сврхом односно функцијом страног језика у двојезичној настави. Овим се, дакле, осим језика наставника и наставних материјала, анализира језик ученика, сврха тог језика из угла наставника.

Наставници у енглеско-српској настави најчешће наводе $р а$ звој иеложивотног учења (скоро две трећине), стицање језичких знана и коришћете вишејезичних извора информација (више од половине) као и развој комуникативне компетенције (скоро половина). У мањој мери стииағе стручних зната (више од трећине), а још мање развој вищејезичности, а остале функције спорадично. За наставнике у немачкосрпској настави главна сврха језика лежи такође у целоживотном учењу (преко три четвртине испитаника) и подједнако у стицағу стручних знаға (за разлику од наставника у енглеско-српској настави који су двоструко мање вредновали ову функцију), затим у развоју комуникативне компетенције (две трећине испитаника) и стицану језичких знана (преко половине). Мање од половине наставника је истакло вишејезичност, док остале функције нису вредноване. Када је у питању Коришћење вишејезичних извора информација, уочљива је разлика између две групе испитаника, јер је више од половине наставника у енглеско-српској билнгвалној настави вредновало исту, за разлику од наставника у немачкосрпској настави који је уопште нису вредновали. Може се уочити велика разлика и у вредновању Стицања стручних знања. Наиме, наставници у немачко-српској настави углавном друштвено-хуманистичких предмета двоструко више вреднују ову функцију језика.

Табела 11. Ставови наставника о аспектима двојезичне наставе

\begin{tabular}{|c|c|c|c|c|c|c|}
\hline & \multicolumn{3}{|c|}{ „Бора Станковић“ } & \multicolumn{3}{|c|}{ „Стеван Сремац“. } \\
\hline & $\begin{array}{c}\text { Слажем } \\
\text { се. }\end{array}$ & $\begin{array}{c}\mathrm{He} \\
\text { слажем } \\
\text { се. }\end{array}$ & $\begin{array}{c}\text { Немам } \\
\text { став. }\end{array}$ & $\begin{array}{c}\text { Слажем } \\
\text { се. }\end{array}$ & $\begin{array}{c}\mathrm{He} \\
\text { слажем } \\
\text { се. }\end{array}$ & $\begin{array}{c}\text { Немам } \\
\text { став. }\end{array}$ \\
\hline $\mid \begin{array}{lll}\text { Страни } & \text { језик } & \text { је } \\
\text { заступљен } & \text { у довољној } \\
\text { мери } & \text { у } & \text { двојезичној } \\
\text { настави } & \text { предмета } \\
\text { предаіем. } & & \end{array}$ & $72,73 \%$ & $18,18 \%$ & $9,09 \%$ & $100 \%$ & --- & --- \\
\hline $\begin{array}{lrr}\text { Страни } & \text { језик } \\
\text { двојезичној } & \text { предметној } \\
\text { настави } & \text { повећава } \\
\text { мотивацију } & \text { за } & \text { учење } \\
\text { предмета струке. }\end{array}$ & $36,36 \%$ & $54,54 \%$ & $9,09 \%$ & $66,67 \%$ & --- & $33,33 \%$ \\
\hline
\end{tabular}


Невенка В. Јанковић

\begin{tabular}{|c|c|c|c|c|c|c|}
\hline $\begin{array}{|lr|}\text { Кроз } & \text { двојезичну } \\
\text { предметну } & \text { наставу } \\
\text { повећавају се } \text { језичке } \\
\text { компетеншиіе ученика. }\end{array}$ & $90,90 \%$ & $9,09 \%$ & --- & $88,89 \%$ & --- & $11,11 \%$ \\
\hline $\begin{array}{l}\text { Oстварује се } \\
\text { и } \\
\text { језиканкција који } \\
\text { двористим у } \\
\text { двојезичној } \\
\text { настави. }\end{array}$ & $63,64 \%$ & --- & $36,36 \%$ & $88,89 \%$ & --- & $11,11 \%$ \\
\hline
\end{tabular}

Последњи блок питања односио се на различите аспекте билингвалне наставе: заступљеност и остварење сврхе/функције страног језика у сопственој настави, а са друге стране језик као мотивација за учење стручних садржаја и двојезична настава као средство повећања језичке компетенције. Велики број испитаника $(72,73 \%)$ у енглеско-српској настави сматра да је страни језик заступлен у довољној мери у двојезичној настави предмета које предају, док само два испитаника нису тог мишљења. Један наставник није дао процену. Међутим, више од половине $(54,54 \%)$ не сматра да се страним језиком повећава мотивација ученика за учене предмета, а малу противтежу чини више од трећине (36,36\%) која сматра супротно. Највећи број испитаника $(90,90 \%)$ сматра да се кроз двојезичну предметну наставу повећавају језичке компетениије ученика, а скоро две трећине $(63,64 \%)$ сматра да је сврха и функиија страног језика који наставник користи у двојезичној предметној настави испуюена (мада једна трећина нема став о томе). У односу на претходну гимназију двоструко више наставника у немачко-српској настави сматра да се страним језиком повећава мотивација ученика за учене предмета струке и не постоји ниједан негативан став по том питању (с тим што постоји једна трећина оних који немају став), а много већи проценат (100\%) сматра да је страни језик заступљен у довољној мери у двојезичној настави предмета које предају, Поред тога, већи је и проценат испитаника и по питању слагања око оствариваға сврхе и функиије страног језика који користе у двојезичној предметној настави, скоро 90\%.

\section{4. Анализа резултата испитивања}

На основу прикупљених података могу се уочити сличности међу испитаницима. Традиција двојезичне наставе у двема нишким гимназијама траје 7 година („Бора Станковић“ од школске 2013/2014. године), односно 6 година („Стеван Сремац“ од школске 2014/2015. године) и у њој учествују углавном искуснији наставници (просечно радни стаж 10 односно 18 година, просечно искуство у двојезичној настави 3 односно 4 године). Предмети обухваћени билингвалном енглеско-српском наста- 
вом углавном су природно-математички, у немачко-српској настави друштвено-хуманистички.

Језички ниво знања наставника се разликује. Као што се могло очекивати, виши ниво поседују наставници који наставу изводе на енглеском језику, а нижи ниво наставници у настави на немачком језику (са дужим наставним стажом). Свесни чињенице да је за двојезичну наставу неопходан виши ниво знања страног језика (самопроцена Б2 до Ц2), сви наставници обе гимназије су спремни за даље усавршавање језика. Највећи број наставника изабрао би курс организован од стране матичне школе, затим плаћени курс у иностранству и индивидуални курс језика.

Интересантно је да већина испитаника (половина у немачкосрпској, две трећине у енглеско-српској билингвалној настави) не препознаје значај лектора. С обзиром на то да је у једној од гимназија након увођења билингвалне наставе био присутан и страни лектор, а да је у другој гимназији периодично присутан страни лектор, за потребе другог пројекта не може се са сигурношћу претпоставити да ли су испитаници протумачили ово питање у једном аспекту - као значај лектора за њихово лично језичко усавршавање, или у дидактичком смислу - избор материјала, припрема наставе и сл.

Сви наставници су свесни потребе за континуираним повећањем језичких компетенција и користе доступне изворе на страним језицима (једни литературу, текстове, музику, ТВ, а други ТВ, апликаиије за учење језика и комуникацију са изворним говорницима). Уочава се значајна разлика у спонтаном начину учења енглеског и немачког језика, јер наставници у немачко-српској билингвалној настави истичу комуникацију са изворним говорницима као најчешћи начин, док је то сасвим занемарљиво код друге групе наставника. Могући разлог је већа упућеност наставника у немачко-српској настави на комуникацију са страним лектором. Друга разлика је у много чешћем читану изворних текстова од стране наставника у енглеско-српској настави, очекивано с обзиром на већу доступност извора на енглеском (медији, интернет итд.). Док половина наставника у немачко-српској настави (иначе ниже процењеног знања) није у прилици да чита, али зато користи апликације за учење језика.

Када је у питању сврха добрих језичких знања у настави, постоји мала разлика међу испитаницима, јер у енглеско-српској настави сви су сагласни да је то повећане језичке компетенције, док то мисли око половине наставника у немачко-српској настави. Сви испитаници имају сличан став о коришћену страних уибеника и додатних наставних материјала на страном језику које подједнако вреднују.

Мишљења у вези са уџбеницима, односно материјалима опти- 
малним за двојезичну наставу, слична су код свих испитаника. Већина се слаже да је најбоље комбиновати домаћи и страни уибеник (скоро половина наставника у енглеско-немачкој и две трећине у немачко-српској билингвалној настави). На другом месту је преведен домаћи уибеник $и$ скрипта на страном језику из више извора. Пошто се ради о питању са могућношћу заокруживања више одговора, уочава се да сви испитаници наводе по неколико ставки, што говори у прилог томе да постоји потреба за коришћењем више извора на више језика, те да не постоји само „један“ добар извор. Подједнак став у погледу корисности домаћег уџбеника имају сви испитаници, и то у негативном смислу. Наиме, само десетак процената свих наставника сматра да је домаћи уџбеник погодан за двојезичну наставу.

Што се тиче сврхе и функције страног језика у двојезичној настави са аспекта ученика, већина обе групе испитаника истиче његову пресудну улогу у процесу целоживотног учења. Високо су вредновани и стицане језичких знана (више од половине), развој комуникативне компетенције (мало више од стране наставника у немачко-српској двојезичној настави) и развој стручних знаюа (двоструко више од стране наставника у немачко-српској двојезичној настави). Најмањи број испитаника увиђа сврху страног језика за развој интеркултурне компетенције, развој интердисциплинарности или комбинацију стицане језичких и стручних знана код ученика. То можемо уочити и за коришћене вишејезичних извора информачија, коју наставници у немачко-српској двојезичној настави уопште нису вредновали (док је солидно вреднована у другој групи наставника).

Скоро сви испитаници су сагласни с тиме да је страни језик заступпен у довољној мери у двојезичној настави предмета које предају и да се кроз двојезичну предметну наставу повећавају језичке компетенције ученика. Велика већина (3/4) свих испитаника сматра да је сврха и функција страног језика који наставник користи у двојезичној предметној настави испуюена. Мишљења о мотивацији коју иначе потврђују истраживања (VOLF 2011: 80) су, ипак, подељена. Наиме, иако половина свих испитаника сматра да страни језик утиче на повећағе мотиващије ученика за учеюе предмета струке, друга половина није сагласна или нема став о томе.

\section{5. Закључна разматрања}

На основу резултата истраживања можемо закључити да је потребно стално језичко усавршавање наставника у двојезичној настави. За наставнике са нижим нивоом језичких знања препоручују се целовити курсеви језика опште намене или вишенедељни боравци у земљи 
циљног језика. У том смислу су за наставнике у немачко-српској двојезичној настави школске 2018/2019. и 2019/2020. године организована два језичка курса у трајању од једног и два семестра које су водили лектори за немачки језик Филозофског факултета.

Ово истраживање је једно од два планирана, при чему ће друго бити фокусирано на методику и дидактику билингвалне наставе, након чега ће бити могуће конципирање стручног усавршавања према потребама наставника, како у погледу језичких тако и методско-дидактичких компетенција.

Могућност едукације наставника може бити у виду акционог истраживања, које би се базирало на рефлексији наставника, а које би водило подизању свесности о појединим аспектима ЦЛИЛ-наставе. На тај начин би наставници кроз самопосматрање наставе стекли увид у когнитивне и метакогнитивне процесе који се одвијају у ЦЛИЛ-настави. На различите могућности едукације ЦЛИЛ-наставника указују Хилјард (2011) и Новотна (2011).

Препорука је да се израде програми квалификације за наставнике у школама у којима постоји билингвална настава, а које би израдила радна група састављена од заинтересованих наставника, представника школа, страних лектора и инструктора предметних методика. Теме и садржаји континуиране квалификације обухватали би питања језичких компетенција и садржаја стручних предмета у складу са потребама наставника и школа, а на основу препорука едукатора који би повезали теорију и праксу ЦЛИЛ-а. Могући су семинари ЦЛИЛ-методике и дидактике, који се иначе периодично организују за наставнике у двојезичној настави или периодично окупљање наставника на семинарима у циљу размене искустава ЦЛИЛ-наставника у пракси и сличне праксе, што препоручује Хилјрад (HILJARD 2011: 9).

Што се тиче циљева интерног пројекта, поменутог на почетку овог рада, допринос основном образовању наставника стручних предмета, али и наставника страних језика који интензивно сарађују са наставницима нејезичких предмета, могао би да се огледа у:

- организовању модула или курсева на основним или мастер студијама (уз повезивање теорије и праксе ЦЛИЛ-а, методику ЦЛИЛ-наставе, планирање часова, оцењивање итд.),

- изради силабуса за (изборне) курсеве страног језика за потребе струке и професије на основним или мастер студијама (терминологија, конкретни текстови, стратегије читања),

- одабиру и припреми наставних материјала за помоћ наставницима, израда практикума/ридера са дидактизацијама текстова 
( јер ово истраживање показало је да наставници домаће уџбенике не сматрају адекватним).

С обзиром на то да је језик наставника у сталној интеракцији са језиком ученика, да заједно уз језик струке, тј. самог градива, чини део школског језика или језика учионице, а посебно у ЦЛИЛ настави која обухвата више језика, осврнућемо се на могући утицај овог истраживања и предложеног усавршавања на саме ученике.

Уколико наставник има за циљ развој целоживотног учења, а затим и вишејезичности, свакако да ће то пренети и на ученике у билингвалној настави, подстичући их својим ставовима. Додуше, иако мали број испитаника има став да језик у ЦЛИЛ настави не доприноси развоју вишејезичности, већина тврди да се у двојезичној предметној настави повећавају језичке компетенције ученика, што показује позитиван и подстицајан однос према језику у билингвалној настави. С друге стране, то се помало може негативно одразити на предмет струке, јер половина наставника (која предаје природно-математичке предмете на енглеском језику) сматра да језик не утиче на повећање мотивације ученика за учење предмета струке, што говори о томе да на узајамни однос језика и стручног предмета утиче врста предмета, или пак сам језик, што може бити предмет новог истраживања, а свакако и тема будућег оспособљавања наставника за билингвалну наставу.

Полазећи од тога да ставови, иначе видљиви кроз понашање и отворено изражавање веровања, могу подржавати или ометати учење (MARŠ, MEHISTO I DR. 2010: 11), и да то важи како за наставнике тако и за ученике, можемо закључити да ставови наставника у овом истраживању према функцији језика у погледу ученика, а то су високовредновано целоживотно учење, стицање језичких знања, стицање стручних знања и развој комуникативне компетенције, свакако могу позитивно утицати на ученике и подстицати их на учење, како језика тако и стручног предмета, али и перманентно стицање нових компетенција.

С обзиром на вишеструке професионалне компетенције у ЦЛИЛ настави којима наставници треба да теже, предложено континуирано усавршавање истих омогућило би са аспекта ученика, дугорочно гледано, повећање ученикових компетенција у стручном предмету, језичких компетенција, дискурсне компетенције, когнитивних академских језичких вештина, комуникативних вештина и интеркултурне комуникативне вештине, повећавајући мотивацију за учење. 


\section{Цитирана литература}

HILJARD 2011: HILLYARD, Susan. „First steps in CLIL: Training the teachers”. Latin American Journal of Content \& Language Integrated Learning, Vol. 4/2 (2011): pp. 1-12. doi:10.5294/laclil.2011.4.2.1 ISSN 2011-6721

LAJZEN 2011: LEISEN, Josef. Praktische Ansätze schulischer Sprachförderung Der sprachsensible Fachunterricht. <www.hss.de/download/111027_RM_ Leisen.pdf>. 17. 9. 2020.

LAJZEN 2013: LEISEN, Josef. Handbuch Sprachförderung im Fach. Sprachsensibler Fachunterricht in der Praxis. Stuttgart: Klett-Verlag, 2013.

KAMINS 1987: CUMMINS, Jim. „Bilingualism, language proficiency and metalinguistic development”. In: Homel, Peter, Palij, Michael, and Aaronson, Doris (eds.). Childhood Bilingualism: Aspects of Linguistic, Cognitive and Social Development. Hillsdale, N.J.: Erlbaum, 1987, pp. 57-73.

KAMINS 2008: CUMMINS, Jim. „BICS and CALP: Empirical and Theoretical Status of the Distinction". In: Hornberger, Nancy. H. (eds.). Encyclopedia of Language and Education, 2nd Edition, Vol. 2: Literacy. New York: Springer Science + Business Media LLC, 2008, pp. 71-83.https://doi.org/10.1007/9780-387-30424-3_36

KOJL 2007: COYLE, Do. „Content and Language Integrated Learning: Towards a Connected Research Agenda for CLIL Pedagogies”. The International Journal of Bilingual Education and Bilingualism, Vol. 10 (2007): pp. 543-562. https://doi.org/10.2167/beb459.0

KOJL, HUD I MARŠ 2010: COYLE, Do, HOOD, Philip, and MARSH, David. Content and Language Integrated Learning. Cambridge, UK: Cambridge University Press, 2010.

MARŠ, MEHISTO I DR. 2010: MARŠ, Dejvid, MEHISTO, Peter i dr. Evropski okvir za obrazovanje CLIL nastavnika. Evropski centar za moderne jezike, Savet Evrope, 2010. <https://www.ecml.at/Resources/ECMLresources/tabid/277/ ID/35/language/fr-FR/Default.aspx>.17. 9. 2020.

NOVOTNA, HADJ-MUSOVA I HOFMANOVA 2001: NOVOTNÁ, Jarmila, HADJ-MOUSSOVA, Zuzana, and HOFMANNOVÁ, Marie. „Teacher Training for CLIL - Competences of a CLIL Teacher”. In: Hejný, Milan and Novotná, Jarmila (eds.). Proceedings SEMT 01. Praha: Univerzita Karlova v Praze-Pedagogicka fakulta, pp. 122-126.

PRAVILNIK O BLIŽIM USLOVIMA ZA OSTVARIVANJE DVOJEZIČNE NASTAVE 2015: Službeni glasnik RS, br. 105/2015.

VOLF 2002: Wolff, Dieter. „Zur Ausbildung von Lehrerinnen und Lehrern für mehrsprachige Bildungsgänge“. In: Breidbach, Stephan et al. (Hrsg.): Bilingualer Sachfachunterricht: Didaktik, Lehrer-, Lernerforschung und Bildungspolitik zwischen Theorie und Empirie. Frankfurt am Main, Berlin: Peter Lang, 2002, S. 253-267.

VOLF 2011: Wolff, Dieter. „Der bilinguale Sachfachunterricht (CLIL): Was dafür spricht, ihn als innovatives didaktisches Konzept zu bezeichnen“. Forum Sprache, Nr. 6 (2011), S. 74-83. 
Невенка Јанковић

\section{LEHRERAUFFASSUNGEN ÜBER DIE FUNKTION DER SPRACHE IM BILINGUALEN SACHFACHUNTERRICHT}

Der bilinguale Sachfachunterricht als Forschungsgegenstand aus der Sicht der Fremdsprachen- als auch Sachfachmethodik- und Didaktik umfasst viele Unterrichtsaspekte. Einer der wichtigsten ist sicherlich die Fremdsprache, und mögliche Forschungsthemen wären Unterrichtssprache, Schülersprache oder Lehrersprache. Das Ziel dieses Beitrags ist die Analyse der Lehrerauffassungen zum Zweck und zur Funktion der Sprache im bilingualen Sachfachunterricht, wobei der Schwerpunkt auf der Lehrersprache liegt. Diese Forschung stellt eine Grundlage für den Einblick in Lehrerbedürfnisse im bilingualen Sachfachunterricht in sprachlicher Hinsicht und für Vorschläge für Sprachfortbildung und Unterrichtsmaterialien dar. Untersucht wurden die Auffassungen der Lehrer an zwei Gymnasien, in denen diese Unterrichtsform seit mehreren Jahren besteht. Die Untersuchung hat ergeben, dass die Erhöhung des Sprachniveaus, die kontinuierliche Sprachverbesserung und fremdsprachliche Materialien notwendig sind, dass unterschiedliche Ansichten zur Rolle eines ausländischen Dozenten/Lektors im bilingualen Unterricht aber ein ähnliches Verständnis des Zwecks und der Funktion einer Fremdsprache im bilingualen Unterricht besteht.

Schlüsselwörter: bilingualer Sachfachunterricht, Funktion der Sprache, Lehrersprache, Unterrichtssprache, Lehrerauffassungen 